\title{
pH-triggered peptide self-assembly into fibrils: a potential peptide-based subunit vaccine delivery platform
}

\author{
Mariusz Skwarczynski*, Jariya Kowapradit, Zyta Maria Ziora and Istvan Toth \\ *Correspondence: m.skwarczynski@uq.edu.au \\ School of Chemistry and Molecular Biosciences, The University of Queensland, Brisbane, Australia.
}

\begin{abstract}
Background: Peptide-based subunit vaccines require strong adjuvants (immunostimulant) for therapeutic potency. There is strong demand for the discovery of new safe adjuvants and vaccine delivery systems that can be produced in a highly controlled manner. The $\mathrm{pH}$ dependent self-assembly of isopeptide derivatives into fibrils has been reported. Appropriately designed fibrils may have adjuvanting potency.

Methods: Isopeptides conjugated to B-cell peptide epitopes (antigens) were synthesized. Properties of the resultant conjugates and their ability to undergo $\mathrm{O}-\mathrm{N}$ intramolecular acyl migration reaction were analysed by HPLC, circular dichroism, and transmission electron microscopy.

Results: The conjugates were converted to "parent" peptides via the pH-triggered O-N acyl migration reaction. The parent peptides aggregated into fibrils. The differences in conjugates composition resulted in different fibril morphology. Aggregation of produced peptides induced desired secondary conformation of antigens (peptide epitopes).

Conclusions: The isopeptide approach presented herein may serve as a new self-adjuvanting delivery system for peptide-based vaccines. Such vaccines could be stable when stored in a non-aggregative form, and then converted on demand to the active form in $\mathrm{pH}$-controlled manner. The use of a vaccine that is solely composed of endogenous components may reduce vaccine-associated side effects.
\end{abstract}

Keywords: O-N acyl migration reaction, isopeptides, peptide-based vaccine, fibrils, peptide conformation, nanotechnology, adjuvant, delivery system

\section{Introduction}

The development of new vaccines is often hampered by significant obstacles: vaccine heterogeneity, toxicity of additives (eg., immunostimulant), side effects (autoimmune and allergic responses), stability, and difficulties with characterization and manufacturing processes [1]. Most of these obstacles can be overcome by the design of a peptide subunit vaccine that contains the minimal microbial components necessary to stimulate an appropriate immune response. Purified, fully characterized synthetic peptides can be produced using modern solid phase peptide synthesis (SPPS). However, peptides alone are poorly immunogenic and need a strong adjuvant (immunostimulant) to elicit the desired immune response [2-4]. Many adjuvants are poorly characterized complex mixtures derived from bacteria. These adjuvants are associated with significant toxicity or poor stimulating activity, thus few are licensed for human use [5]. There is strong demand for the discovery of safe, new adjuvants and delivery systems that can be produced in a highly controlled manner $[6,7]$. Several approaches have been reported to overcome adjuvant-associated side effects $[\mathbf{1 , 6 ]}$. We have extensively used exogenous lipids and polymers to form self-adjuvanting delivery systems that obviate the use of toxic adjuvants [8-13]. Recently, it has been reported that self-assembled peptides exclusively composed of endogenous amino acids were able to stimulate immune responses [14-16].

Peptide self-assembly into extracellular matrices has been studied extensively [17], and the self-assembly of O-acyl isopeptides-polymer conjugates was recently reported $[18,19]$. O-acyl isopeptides were originally used for the synthesis of peptides that contained difficult sequences. In this method a native amide bond at a serine or threonine residue was isomerized to form an ester bond. Upon the completion of peptide synthesis, the native peptide bond was restored via an $\mathrm{O}-\mathrm{N}$ intramolecular acyl migration reaction [20-23]. O-N acyl isomerization (Figure 1) allowed drastic changes to the properties of the peptide.

Herein, we describe the application of an $\mathrm{O}-\mathrm{N}$ intramolecular acyl migration reaction to the design of a potential vaccine delivery system which is able to self-assemble to form fibrils. Appropriately designed $\mathrm{O}-\mathrm{N}$ isopeptides were conjugated by azide alkyne cycloaddition with B-cell peptide epitopes. The conjugates were only able to adopt $\beta$-sheet conformation and self-assemble to form fibrils upon $\mathrm{pH}$-triggered intramolecular acyl migration, and their $\mathrm{O}$-acyl isoforms were stable in the non-aggregative form.

\section{Methods \\ General}

Protected L-amino acids were obtained from Novabio-chem 


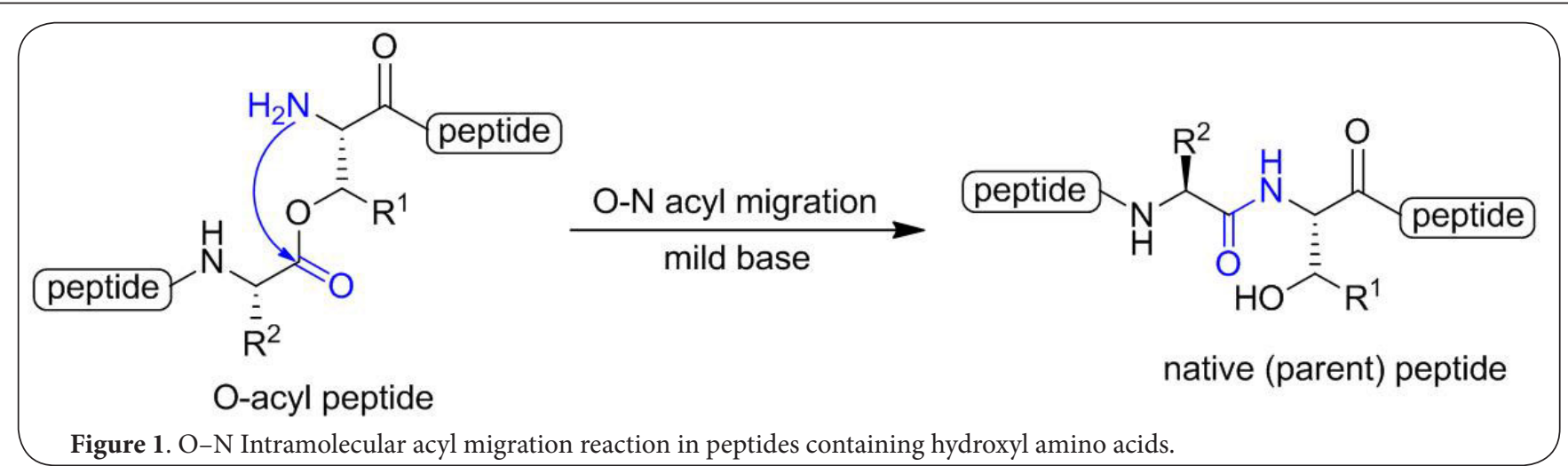

(Läufelfingen, Switzerland), Reanal (Budapest, Hungary) or Mimotopes (Melbourne, Australia). Rink amide MBHA resin, $\mathrm{N}, \mathrm{N}^{\prime}$-dimethylformamide (DMF), dichloromethane (DCM), methanol, $\mathrm{N}, \mathrm{N}^{\prime}$-diisopropylethylamine (DIPEA), piperidine and trifluoroacetic acid (TFA) were obtained from Merck (Hohenbrunn, Germany). 1-(1H-Benzotriazol-1-yl)-1,1,3,3tetramethyluroniumhexafluorophosphate (HBTU) was purchased from Mimotopes (Melbourne, Australia). All other reagents were obtained at the highest available purity from Sigma-Aldrich (Castle Hill, NSW,Australia). ESI-MS was performed on a Perkin-Elmer-Sciex API3000 instrument with Analyst 1.4 software (Applied Biosystems/MDS Sciex, Toronto, Canada). Analytical RP-HPLC was performed on an Agilent instrument with a $1 \mathrm{mLmin}^{-1}$ flow rate and detection at $214 \mathrm{~nm}$. Separation was achieved by running gradient mode of $0-100 \%$ solvent $B$ over 40 min with $0.1 \% \mathrm{TFA} / \mathrm{H}_{2} \mathrm{O}$ as solvent $\mathrm{A}$ and $90 \%$ acetonitrile/0.1\% TFA/ $\mathrm{H}_{2} \mathrm{O}$ as solvent $\mathrm{B}$ on a Vydac analytical C18 column (218TP54; $5 \mathrm{~mm}, 4.6 \times 250 \mathrm{~mm}$ ). Purification was carried out by preparative RP-HPLC using a Waters Delta 600 system with a $10 \mathrm{mLmin}^{-1}$ flow rate. Compounds were detected at $230 \mathrm{~nm}$. Separations were performed with solvent $A$ and solvent $B$ on a Vydac preparative C18 column (218TP1022; 10 $\mathrm{mm}, 22 \times 250 \mathrm{~mm}$ ). A Zetasizer Nano ZP instrument (Malvern Instruments, UK) with DTS software was used for particle size measurements. Sizes were analyzed using a non-invasive back scatter system. Measurements were taken at $25^{\circ} \mathrm{C}$ with a scattering angle of $173^{\circ}$ using disposable cuvettes.

\section{Synthesis}

\section{Boc-Thr(Fmoc-Val)-OH}

The isodipeptide unit was prepared as previously described [24-26].

\section{Isopeptide 1}

Isopeptide 1 was synthesized using Fmoc-chemistry on Rink amide MBHA resin by SPPS. Fmoc-amino acids (3.2 equiv.) activated with HBTU (3.0 equiv.) and DIPEA (3.2 equiv.) were coupled to the peptide resin $(2 \times 2 \mathrm{~h})$. The isodipeptide unit Boc-Thr(Fmoc-Val)-OH (3.2 equiv.) activated with HBTU (3.0 equiv.) and DIPEA (3.2 equiv.) was coupled to the peptide resin $(3 \mathrm{~h}+$ overnight). Amino acids were coupled in the following order: Fmoc-Gly-OH, Fmoc-Val-OH, Fmoc-Val-OH, Boc-Thr (Fmoc-Val)-OH, Fmoc-Val-OH, Boc-Thr (Fmoc-Val)-OH, FmocVal-OH. Each Fmoc deprotection was performed with $20 \%$ piperidine ( 1 x $10 \mathrm{~min}, 1 \times 20 \mathrm{~min}$ ). Compound 1 was cleaved from the resin using a solution of TFA/triisopropylsilane/water (95:2.5:2.5) for 4 hours. The resultant compound was purified by preparative HPLC using a C18 column with a gradient of solvent B. HPLC analysis (C18 column): $t_{R}=15.83$ min, purity > 95\%. Yield: $27 \%$. ESI-MS: $m / z 871.8$ (calc 871.1) $[\mathrm{M}+\mathrm{H}]^{+} ; 436.7$ (calc 436.5) $[\mathrm{M}+2 \mathrm{H}]^{2+} ; \mathrm{MW}: 871.08$.

\section{Isopeptide 2}

Isopeptide $\mathbf{2}$ was synthesized using the above SPPS procedure, with the further addition of Boc-Thr(Fmoc-Val)-OH and Fmoc$\mathrm{Val}-\mathrm{OH}$ before cleavage from the resin.

HPLC analysis (C18 column): $t_{R}=16.66$ min, purity $>95 \%$. Yield: $37 \%$. ESI-MS: $\mathrm{m} / z 1172.2$ (calc 1171.4) $[\mathrm{M}+\mathrm{H}]^{+} ; 586.2$ (calc 586.2) $[\mathrm{M}+2 \mathrm{H}]^{2+} ; 391.2$ (calc 391.1) $[\mathrm{M}+3 \mathrm{H}]^{3+} ; \mathrm{MW}: 1170.44$.

\section{Isopeptide 3}

Isopeptide $\mathbf{3}$ was synthesized in the same manner as isopeptide 1, with the addition of Fmoc-Gly followed by azidoacetic acid at the $\mathrm{N}$-terminus of the peptide. HPLC analysis ( 18 column): $t_{R}=17.76$ min, purity > 95\%. Yield: 23\%. ESI-MS: $m / z 1011.9$ (calc 1012.2) $[\mathrm{M}+\mathrm{H}]^{+} ; 506.4$ (calc 506.6) $[\mathrm{M}+2 \mathrm{H}]^{2+} ; \mathrm{MW}: 1011.18$.

\section{Isopeptide 4}

Isopeptide $\mathbf{4}$ was synthesized in the same manner as isopeptide 2, with the addition of Fmoc-Gly followed by azidoacetic acid at the $\mathrm{N}$-terminus of the peptide. HPLC analysis (C18 column): $t_{R}=18.60 \mathrm{~min}$, purity $>95 \%$. Yield: $18 \%$. ESI-MS: $\mathrm{m} / \mathrm{z} 1311.2$ (calc 1311.5) $[\mathrm{M}+\mathrm{H}]^{+} ; 656.3$ (calc 656.3) $[\mathrm{M}+2 \mathrm{H}]^{2+} ; 438.0$ (calc 437.8) $[\mathrm{M}+3 \mathrm{H}]^{3+} ; \mathrm{MW}: 1310.54$.

\section{Peptide epitope 5}

Peptide 5 (J14) was synthesized as previously reported [27].

\section{Peptide epitope 6}

Peptide 6 (88/30 with Gly spacer on C-terminus) was synthesized using standard Fmoc-SPPS in a similar manner to peptide 1, but without the use of the isodipeptide building 
block. HPLC analysis (C18 column): $t_{R}=17.60$ min, purity $>$ 95\%. ESI-MS: $\mathrm{m} / \mathrm{z} 1172.3$ (calc1172.3) $[\mathrm{M}+2 \mathrm{H}]^{2+} ; 782.0$ (calc 781.9) $[\mathrm{M}+3 \mathrm{H}]^{3+} ; 586.7$ (calc 586.6) $[\mathrm{M}+4 \mathrm{H}]^{4+} ; 469.6$ (calc 469.5) $[\mathrm{M}+5 \mathrm{H}]^{5+} ; \mathrm{MW}: 2342.57$.

\section{Peptide epitope 7}

Peptide $7\left(\mathrm{CHCC}(\mathrm{O}) \mathrm{HNCH}_{2} \mathrm{C}(\mathrm{O}) \mathrm{J14}\right)$ was synthesized in the same manner as peptide $\mathbf{5}$, with the addition of a glycine spacer at the $\mathrm{N}$-terminus followed by a propiolic acid (4.0 equiv.) activated with $\mathrm{N}$-ethoxycarbonyl-2-ethoxy-1,2dihydroquinoline (EEDQ, 4.0 equiv.) was coupled $(2 \times 2 \mathrm{~h}$ ) to the peptide. HPLC analysis (C18 column): $t_{R}=19.58 \mathrm{~min}$, purity $>95 \%$. ESI-MS: $m / z 1732.7$ (calc 1732.5) $[\mathrm{M}+2 \mathrm{H}]^{2+} ; 1156.2$ (calc 1156.6) $[\mathrm{M}+3 \mathrm{H}]^{3+} ; 866.9$ (calc 867.7) $[\mathrm{M}+4 \mathrm{H}]^{4+} ; 693.8$ (calc 693.6) $[\mathrm{M}+5 \mathrm{H}]^{5+} ; 578.2$ (calc 578.2) $[\mathrm{M}+6 \mathrm{H}]^{6+} ; 496.8$ (calc 495.7) $[\mathrm{M}+7 \mathrm{H}]^{7+} ; 434.1$ (calc 433.9) $[\mathrm{M}+8 \mathrm{H}]^{8+} ; \mathrm{MW}: 3462.91$.

\section{Peptide epitope 8}

Peptide $\mathbf{8}$ was synthesized in the same manner as peptide $\mathbf{6}$, with the addition of a glycine spacer at the $\mathrm{N}$-terminus, followed by a propiolic acid. HPLC analysis (C18 column): $t_{R}$ $=18.00 \mathrm{~min}$, purity > 95\%. ESI-MS: $\mathrm{m} / \mathrm{z} 1227.4$ (calc 1226.8) $[\mathrm{M}+2 \mathrm{H}]^{2+} ; 818.3$ (calc 818.2) $[\mathrm{M}+3 \mathrm{H}]^{3+} ; 614.1$ (calc 613.9) $[\mathrm{M}+4 \mathrm{H}]^{4+} ; \mathrm{MW}: 2451.65$.

\section{Conjugate (9) of compounds 3 and 7}

The conjugation was performed as previously described $[27,28]$. Briefly, compounds $3\left(2.05 \mathrm{mg}, 1.65 \times 10^{-3} \mathrm{mmol}\right)$ and $7\left(7.41 \mathrm{mg}, 1.65 \times 10^{-3} \mathrm{mmol}\right)$ were dissolved in DMF $(1 \mathrm{~mL})$ and copper wires were added $(70 \mathrm{mg})$. The reaction mixture was protected from light and stirred at $50^{\circ} \mathrm{C}$ for 3 hours under nitrogen atmosphere. The resultant compound was purified by preparative HPLC using a C18 column with a gradient of solvent B. HPLC analysis (C18 column): $t_{R}=19.76 \mathrm{~min}$, purity $>95 \%$, Yield: 36\%. ESI-MS: $\mathrm{m} / \mathrm{z} 1119.9$ (calc1119.5) $[\mathrm{M}+4 \mathrm{H}]^{4+}$; 895.9 (calc895.8) $[\mathrm{M}+5 \mathrm{H}]^{5+} ; 746.9$ (calc746.7) $[\mathrm{M}+6 \mathrm{H}]^{6+} ; 640.2$ (calc640.1) $[\mathrm{M}+7 \mathrm{H}]^{7+} ; 560.4$ (calc560.3) $[\mathrm{M}+8 \mathrm{H}]^{8+} ; 498.4$ (calc 498.1) $[\mathrm{M}+9 \mathrm{H}]^{9+} ; 448.6$ (calc 448.4) $[\mathrm{M}+10 \mathrm{H}]^{10+} ; \mathrm{MW}: 4474.08$.

\section{Conjugate (10) of compounds 3 and 8}

Conjugation was performed as described for compound 9 . HPLC analysis (C18 column): $t_{R}=18.61 \mathrm{~min}$, purity $>95 \%$, Yield: $37 \%$. ESI-MS: $\mathrm{m} / \mathrm{z} 1732.5$ (calc 1732.4) $[\mathrm{M}+2 \mathrm{H}]^{2+} ; 1156.6$ (calc 1155.3) $[\mathrm{M}+3 \mathrm{H}]^{3+} ; 867.0$ (calc 866.7) $[\mathrm{M}+4 \mathrm{H}]^{4+} ; 693.7$ (calc 693.6) $[\mathrm{M}+5 \mathrm{H}]^{5+} ; 578.4$ (calc 578.1) $[\mathrm{M}+6 \mathrm{H}]^{6+} ; \mathrm{MW}: 3462.83$.

\section{Conjugate (11) of compounds 4 and 7}

Conjugation was performed as described for compound 9. HPLC analysis (C18 column): $t_{R}=19.85$ min, purity $>95 \%$, Yield: 38\%. ESI-MS: $\mathrm{m} / \mathrm{z} 1593.0$ (calc 1592.1) $[\mathrm{M}+3 \mathrm{H}]^{3+} ; 1194.5$ (calc 1194.4) $[\mathrm{M}+4 \mathrm{H}]^{4+} ; 955.9$ (calc 955.7) $[\mathrm{M}+5 \mathrm{H}]^{5+} ; 797.1$ (calc 796.6) $[\mathrm{M}+6 \mathrm{H}]^{6+} ; 682.9$ (calc 682.9) $[\mathrm{M}+7 \mathrm{H}]^{7+} ; 597.9$ (calc 597.7) $[\mathrm{M}+8 \mathrm{H}]^{8+} ; 531.7$ (calc 531.4) $[\mathrm{M}+9 \mathrm{H}]^{9+} ; 478.2$ (calc 478.3) $[\mathrm{M}+10 \mathrm{H}]^{10+} ; \mathrm{MW}: 4773.45$.

\section{Conjugate (12) of compounds 4 and 8}

Conjugation was performed as described for compounds 9. $\mathrm{HPLC}$ analysis (C18 column): $t_{R}=18.82 \mathrm{~min}$, purity $>95 \%$, Yield: $31 \%$. ESI-MS: $\mathrm{m} / \mathrm{z} 1255.5$ (calc 1255.1) $[\mathrm{M}+3 \mathrm{H}]^{3+} ; 941.8$ (calc 941.6) $[\mathrm{M}+4 \mathrm{H}]^{4+} ; 753.4$ (calc 753.7) $[\mathrm{M}+5 \mathrm{H}]^{5+} ; 628.2$ (calc 628.0); MW: 3762.19.

\section{$\mathrm{O}-\mathrm{N}$ intramolecular acyl migration}

Conversion of isopeptides 9-12 into the parent peptide 13-16 was based on previously published methods [26]. Briefly, the isopeptide $(\mathbf{9}, \mathbf{1 0}, \mathbf{1 1}$, or $\mathbf{1 2} ; 5 \mu \mathrm{L}$ at $10 \mathrm{mM}$ in DMSO) was added to phosphate buffered saline (PBS, $495 \mu \mathrm{L}, \mathrm{pH} 7.4$ ) and the mixture was shaken at RT. At the desired time points ( $0 \mathrm{~h}, 1 \mathrm{~h}, 2 \mathrm{~h}$, etc.), $60 \mu \mathrm{L}$ samples were taken from the mixture, diluted with an equal volume of DMSO and directly analysed by HPLC. HPLC was performed with a linear gradient of solvent B $(0-100 \%, 40 \mathrm{~min})$. The results were analysed at $214 \mathrm{~nm}$.

\section{$\mathrm{CD}$ analysis}

CD spectra were measured on a JASCO (Tokyo, Japan) J-710 spectropolarimeter using a quartz cuvette with a $1 \mathrm{~mm}$ path length at $23^{\circ} \mathrm{C}$. The conjugate samples were analysed either freshly dissolved in water or in buffer $(\mathrm{pH}=7.4)$ upon completion of O-N acyl migration. $\mathrm{CD}$ spectra of isopeptides 9-12 were measured at $0.1 \mathrm{mM}$ concentration. To avoid suspension formation, CD spectra of peptides 13-16 were measured immediately after migration reaction at $0.05 \mathrm{mM}$ concentration.

\section{Transmission electron microscopy (TEM)}

A sample of the conjugate was added to glow discharged carbon coated 200 mesh grids for $3 \mathrm{~min}$ and then wicked off with filter paper. Pictures were taken from a JEM-1010 transmission electron microscope (JEOL Ltd., Japan) operated at $80 \mathrm{kV}$.

\section{Results and discussion}

In recent years, nanotechnology has been widely applied to the study of new adjuvant formulations and vaccine delivery systems $[1,29,30]$. The ability of vaccines (or their delivery systems) to self-assemble in nanoscale was found to be important for inducing immune responses. For example, it was demonstrated that small nanoparticles $(20-40 \mathrm{~nm})$ are preferable for the induction of strong humoral immunity. The self-adjuvanting activity of nanofibers, several micrometres in length fibrils with widths of around $15 \mathrm{~nm}$, was also reported [14]. These fibrils caring model peptide were able to elicit high IgG titers without adjuvant in mice. We proposed that an appropriately designed O-acyl isopeptide could be used as a $\beta$-sheet-based fibril precursor with potential self-adjuvanting activity. Valine-rich peptides conjugated to poly(ethylene oxide) have previously been reported to be able to self-assemble into fibrils $[18,19]$. Thus, $\beta$-sheet precursor isopeptides $\mathbf{1 - 4}$, which were rich in valine moieties, 


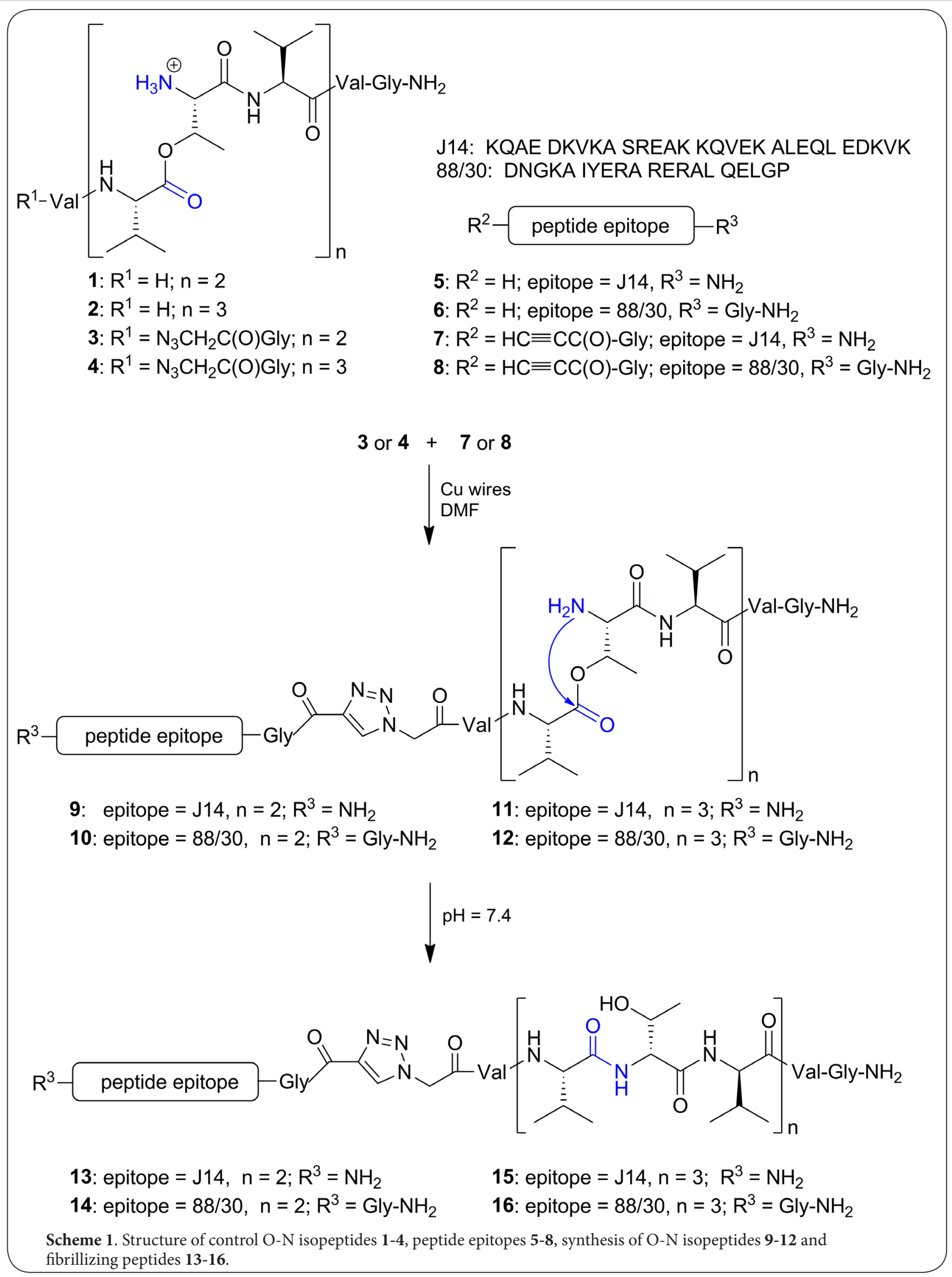

fibrillizing peptides 13-16. 

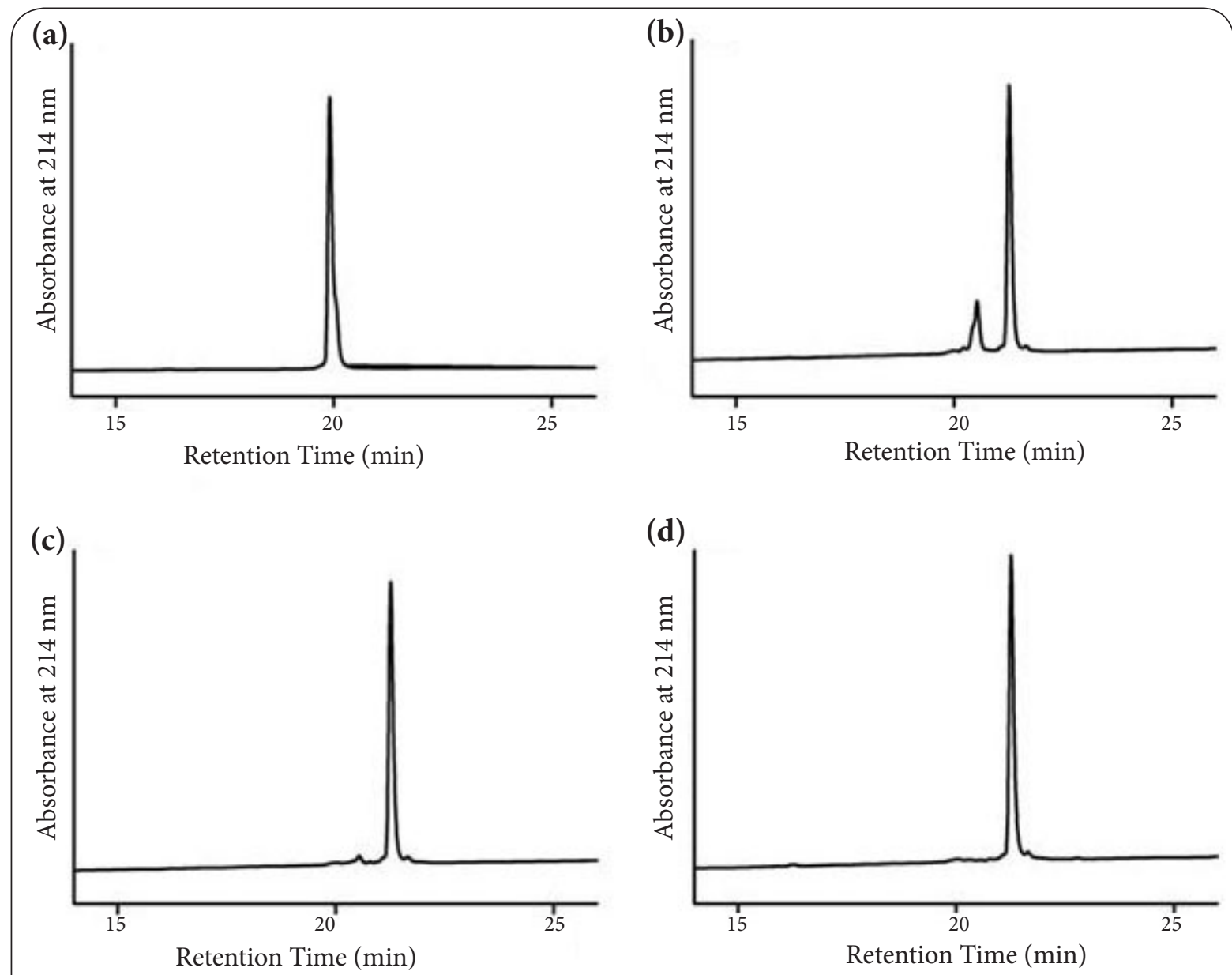

Figure 2. HPLC charts of $\mathrm{pH}$-triggered conversion of isopeptide 9 via $\mathrm{O}-\mathrm{N}$ intramolecular acyl migration into peptide 13 at (a) $0 \mathrm{~h}$; (b) $1 \mathrm{~h}$; (c) $2 \mathrm{~h}$; (d) 1 day in PBS ( $\mathrm{pH}=7.4$ ).

were designed (Scheme 1). B-cell peptide epitopes derived from Group A Streptococcus (GAS) M-protein were chosen as model antigens.

A chimeric peptide, J14 (KQAEDKVKASREAKKQVEKA$L E Q L E D K V K$ ) contains the minimal protective epitope (in italic) enclosed within yeast helical "promoting" sequence from yeast protein CGN4. This peptide is derived from a conserved fragment of Group A streptococcal M-protein that has a tendency to adopt a helical conformation and has been widely used for the development of peptide based vaccines [31-33]. The second B-cell epitope, 88/30 (DNGKAIYERARERALQELGP), was derived from the $\mathrm{N}$-terminal hyper variable region of GAS M-protein, and has a tendency to form random coil rather than an ordered conformation. This epitope has also been used for the development of a vaccine against GAS [34-36]. The peptides were synthesized by SPPS. Due to coupling difficulties, glycine was introduced as a linker (the first C-terminal amino acid) during synthesis of $88 / 30$ peptide on the resin. The isopeptides were modified with an azide moiety by coupling azidoacetic acid to their $\mathrm{N}$-termini, while the peptide epitopes were modified with the addition of a propiolic acid to the $\mathrm{N}$-termini. A glycine spacer was used between the azide or alkyne moiety and the peptides to reduce steric hindrance around these functional groups. Peptide epitopes $\mathbf{7}$ and $\mathbf{8}$ were conjugated to isopeptide $\mathbf{3}$ and 4 by 1,3-dipolar copper catalyzed alkyne-azide cycloaddition (CuAAC or click) reaction to form four conjugates 9-12 (Scheme 1). It was found that the isopeptides were completely stable at $4^{\circ} \mathrm{C}$ for at least 3 weeks. In general, isopeptides in the solid form are very stable; stability at $4^{\circ} \mathrm{C}$ for up to two years has previously been reported $[26,37]$.

The ability to convert isopeptides 9-12 to their "native" form (13-16) was examined in PBS ( $\mathrm{pH}=7.4)$ and monitored by HPLC. The conversion of isopeptide 9 to peptide $\mathbf{1 3}$ is illustrated in (Figure 2) as an example of this reaction. It is well documented that isopeptides are stable at acidic $\mathrm{pH}$ but undergo relatively quick and irreversible isomerization into the parent peptide (Figure 1) under basic $\mathrm{pH}[22,37]$. In the case of isopeptide $\mathbf{9}$, both isodipeptide units are required to undergo O-N acyl migration reactions to form the desired peptide $\mathbf{1 3}$ 


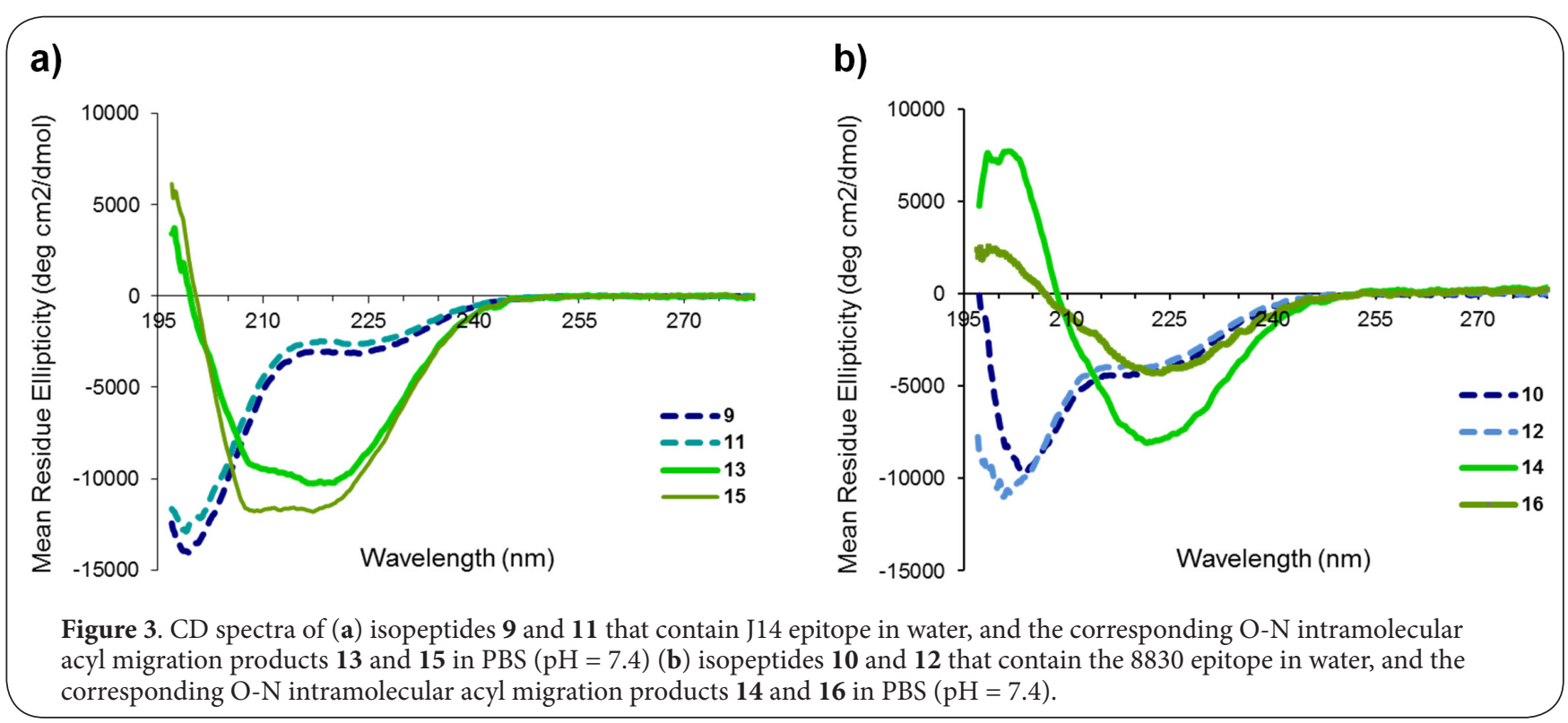

(Scheme 1). At physiological pH (7.4) $97 \%$ of 9 had converted to 13 after two hours. After one day of reaction, no compound with an ester was detected. In contrast, $97 \%$ of the isopeptide $\mathbf{1 0}$ was converted into fully "migrated" peptide $\mathbf{1 4}$ after one day, while after 3 days of reaction only $83 \%$ and $53 \%$ of conversion was detected for peptides 15 and 16 , respectively. Extension of the reaction time above 3 days did not result in further conversion. This observation can be easily explained by the fact that both $\mathbf{1 5}$ and $\mathbf{1 6}$ possessed 3 isodipeptide units which need to undergo the $\mathrm{O}-\mathrm{N}$ migration reaction to form the final product. Indeed, several partially migrated byproducts were detected by HPLC, which were unable to undergo further O-N acyl migration reactions, most likely due to steric hindrance associated with $\beta$-sheet formation and extensive product fibrillization (data not shown). In all cases, the migration product formed a milky suspension, in contrast to the completely soluble starting isopeptides.

$\mathrm{CD}$ analysis was performed to determine the change in secondary structure of peptides before and after O-N acyl migration (Figure 3). As a general rule for CD spectroscopy of peptides, a noticeable double minimum around 208 and 222 $\mathrm{nm}$ indicate san a-helical structure, while a single minimum at $204 \mathrm{~nm}$ is characteristic of random coil, and single minimum at $217 \mathrm{~nm}$ indicates $\beta$-sheet. Isopeptides 9-12 adopted a random conformation regardless of the peptide epitopes incorporated into the conjugates. Interestingly, after O-N acyl migration, the resulting peptide showed a more organized secondary structure. Conjugates that possessed J14 showed rather helical and $\beta$-sheet conformations with shallow minimum at 208 and 216-219 $\mathrm{nm}$ for both $\mathbf{1 3}$ and 15. This outcome can be explained by the predisposition of J14 to form a helical structure and the valine-rich peptide to form a $\beta$-sheet (Figure 3a). Indeed, in the case of the conjugates that possessed the $88 / 30$ epitope, only the induction of a $\beta$-sheet-like conformation was detected after migration, with a single minimum at $220-221 \mathrm{~nm}$ on the $C D$ spectrum (Figure $3 \mathbf{b}$ ). This data suggested that upon commencement of the $\mathrm{pH}$-triggered intramolecular $\mathrm{O}-\mathrm{N}$ acyl migration reaction, the initial isopeptides were converted to poorly soluble products which have a strong tendency to self-assemble via the formation of $\beta$-sheets. This method induced formation of helical structures at a similar degree to that previously observed with self-assembled and selfadjuvanting nanoparticles $[13,27,38]$.

Formation of a milky solution after migration suggested that $\beta$-sheet conformation induce aggregation and fibril formation, in similar manner to other $\beta$-sheet peptides [39]. To investigate this hypothesis, TEM images of peptides 13-16 were recorded. As shown in (Figure 4), extensive fibril formation was detected. However, while conjugate $\mathbf{1 3}$ formed typical long fibrils with diameter around $10 \mathrm{~nm}$, it was difficult to observe individual fibrils in the TEM image of compound $\mathbf{1 4}$. Both conjugates $\mathbf{1 5}$ and $\mathbf{1 6}$ formed similar short aggregated fibrils with a rod-like shape. Thus, the aggregation behaviour and shape of the fibrils produced depended more strongly on the number of isodipeptide units in the conjugate than on the nature of the peptide epitope.

We demonstrated that isopeptides conjugated to peptide epitopes were able to undergo $\mathrm{pH}$-triggered $\mathrm{O}-\mathrm{N}$ acyl migration and self-assemble into fibrils. This process induced the desired conformational properties of the peptide epitopes (eg., helicity of the J14 peptide). These conjugates can be stored in their isopeptide form as a precursor of a peptide-based vaccine and be transformed into the fibril-like structure just before administration in vivo. Alternatively, an isopeptide can be administered and undergo conversion to "parent" peptide in vivo, thus acting as the prodrug of a vaccine. The ability to convert an isopeptide to the parent peptide under cellular media conditions has been already confirmed in the case of 


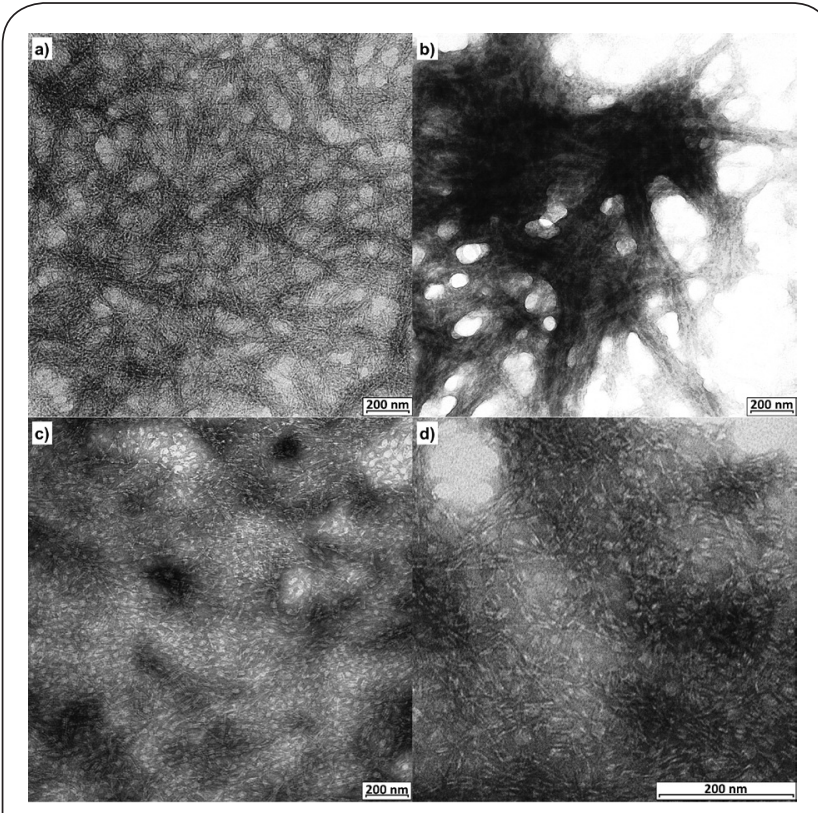

Figure 4. TEM images of compound (a) 13; (b) 14; (c) 15; (d) 16 in PBS (bar $200 \mathrm{~nm}$ ). Samples were stained with $2 \%$ of uranyl acetate.

amyloid peptide $A \beta 1-42$ [40].

\section{Conclusions}

New self-adjuvanting delivery systems are vital for the development of safe and effective peptide-based vaccines. It has been shown that fibrils may be an effective delivery system; therefore we examined the ability of isopeptides to selfassemble into fibrils via the $\mathrm{pH}$-triggered $\mathrm{O}-\mathrm{N}$ intramolecular migration reaction. The conjugates of valine-rich isopeptides and B-cell peptide epitopes (which served as an antigen) were synthesized, and their ability to form fibril-like structures was confirmed. Antigens in these conjugates were able to adopt the desired "native" conformation. The approach presented herein may serve as a new delivery system for peptide-based vaccines. An isopeptide-based vaccine could be stored in a non-aggregative form, and then converted to its active form prior to administration. This would circumvent the storage related over-aggregation, precipitation, and changes in other properties of fibril-based vaccines. In addition, very limited toxicity of such a vaccine could be expected because it is composed solely of endogenous components.

\section{Competing interests}

The authors declare that they have no competing interests.

\section{Authors' contributions}

MS generated the idea, designed and coordinated the research, analysed and compiled the data, and wrote the manuscript. JK synthesized and analysed the conjugates. ZZ performed and analysed the TEM experiment. IT coordinated the research and wrote the manuscript. The final manuscript was read and approved by all of the authors.
There won't be any further changes in the authorship which includes either addition or removal of author's details and Mariusz Skwarczynski will be sole responsible person for all the communications and proceedings that are needed to be done with the publisher (According to the necessity of the publisher) on behalf of all the authors.

\section{Acknowledgement and funding}

This work was supported by the National Health and Medical Research Council of Australia (NHMRC 1006454). We thank Thalia Guerin for her critical review of the manuscript.

\section{Publication history}

Editor: Laszlo Otvos, Temple University, USA.

EIC: John Wade, University of Melbourne, Australia.

Received: 16-May-2013 Revised: 20-Jun-2013

Accepted: 28-Jun-2013 Published: 05-Jul-2013

\section{References}

1. Skwarczynski M and Toth I: Peptide-based subunit nanovaccines. Curr Drug Deliv 2011, 8:282-9. | Article | PubMed

2. Skwarczynski M, Zaman M and Toth I: Lipo-peptides/saccharides in peptide vaccine delivery. In Handbook of the Biologically Active Peptides, the 2nd Edition, Kastin, A., Ed. Elsevier Inc: Burlington, 2013, pp 571-579. | Book

3. Simerska P, Moyle PM and Toth I: Modern lipid-, carbohydrate-, and peptide-based delivery systems for peptide, vaccine, and gene products. Med Res Rev 2011, 31:520-47. | Article | PubMed

4. Dudek NL, Perlmutter P, Aguilar MI, Croft NP and Purcell AW: Epitope discovery and their use in peptide based vaccines. Curr Pharm Des 2010, 16:3149-57. | Article | PubMed

5. Montomoli E, Piccirella S, Khadang B, Mennitto E, Camerini R and De Rosa A: Current adjuvants and new perspectives in vaccine formulation. Expert Rev Vaccines 2011, 10:1053-61. | Article | PubMed

6. Moyle PM and Toth I: Modern subunit vaccines: development, components, and research opportunities. ChemMedChem 2013, 8:36076. | Article | PubMed

7. Giddam AK, Zaman M, Skwarczynski M and Toth I: Liposome-based delivery system for vaccine candidates: constructing an effective formulation. Nanomedicine (Lond) 2012, 7:1877-93. | Article | PubMed

8. Ahmad Fuaad AA, Jia Z, Hartas J, Ziora ZM, Lin IC, Moyle PM, Batzloff MR, Good MF, Monteiro MJ, Skwarczynski M and Toth I: Polymerpeptide hybrids as a highly immunogenic single-dose nanovaccine. Nanomedicine (Lond) 2013. I Article | PubMed

9. Skwarczynski M, Dougall AM, Khoshnejad M, Chandrudu S, Pearson MS, Loukas A and Toth I: Peptide-based subunit vaccine against hookworm infection. PLoS One 2012, 7:e46870. | Article | PubMed Abstract | PubMed Full Text

10. Apte SH, Groves PL, Skwarczynski M, Fujita Y, Chang C, Toth I and Doolan DL: Vaccination with lipid core peptides fails to induce epitope-specific $T$ cell responses but confers non-specific protective immunity in a malaria model. PLoS One 2012, 7:e40928. | Article | PubMed Abstract | PubMed Full Text

11. Zaman M, Skwarczynski M, Malcolm JM, Urbani CN, Jia Z, Batzloff MR, Good MF, Monteiro MJ and Toth I: Self-adjuvanting polyacrylic nanoparticulate delivery system for group $A$ streptococcus (GAS) vaccine. Nanomedicine 2011, 7:168-73. | Article | PubMed

12. Skwarczynski $M$ and Toth I: Lipid-core-peptide system for selfadjuvanting synthetic vaccine delivery. Methods Mol Biol 2011, 751:297-308 8. | Article | PubMed

13. Skwarczynski M, Zaman M, Urbani CN, Lin IC, Jia Z, Batzloff MR, Good MF, Monteiro MJ and Toth I: Polyacrylate dendrimer nanoparticles: a self-adjuvanting vaccine delivery system. Angew Chem Int Ed Engl 2010, 49:5742-5. I Article I PubMed

14. Rudra JS, Tian YF, Jung JP and Collier JH: A self-assembling peptide 
Skwarczynski et al. Biochemical Compounds 2013,

acting as an immune adjuvant. Proc Natl Acad Sci U S A 2010, 107:622-7. | Article | PubMed Abstract | PubMed Full Text

15. Kaba SA, Brando C, Guo Q, Mittelholzer C, Raman S, Tropel D, Aebi U, Burkhard $\mathrm{P}$ and Lanar DE: A nonadjuvanted polypeptide nanoparticle vaccine confers long-lasting protection against rodent malaria. $J$ Immunol 2009, 183:7268-77. | Article | PubMed

16. Pimentel TA, Yan Z, Jeffers SA, Holmes KV, Hodges RS and Burkhard P: Peptide nanoparticles as novel immunogens: design and analysis of a prototypic severe acute respiratory syndrome vaccine. Chem Biol Drug Des 2009, 73:53-61. | Article | PubMed Abstract | PubMed Full Text

17. Collier JH, Rudra JS, Gasiorowski JZ and Jung JP: Multi-component extracellular matrices based on peptide self-assembly. Chem Soc Rev 2010, 39:3413-24. | Article | PubMed Abstract | PubMed Full Text

18. Hentschel J and Borner HG: Peptide-directed microstructure formation of polymers in organic media. J Am Chem Soc 2006, 128:14142-9. | Article I PubMed

19. Hentschel J, Krause E and Borner HG: Switch-peptides to trigger the peptide guided assembly of poly(ethylene oxide)-peptide conjugates into tape structures. J Am Chem Soc 2006, 128:7722-3. | Article | PubMed

20. Skwarczynski $\mathrm{M}$ and Kiso Y: Application of the $\mathbf{O}-\mathbf{N}$ intramolecular acyl migration reaction in medicinal chemistry. Curr Med Chem 2007, 14:2813-23. | Article | PubMed

21. Sohma Y, Taniguchi A, Yoshiya T, Chiyomori Y, Fukao F, Nakamura S, Skwarczynski M, Okada T, Ikeda K, Hayashi Y, Kimura T, Hirota S, Matsuzaki K and Kiso Y: 'Click peptide': a novel ‘O-acyl isopeptide method' for peptide synthesis and chemical biology-oriented synthesis of amyloid beta peptide analogues. J Pept Sci 2006, 12:823-8. | Article PubMed

22. Sohma Y, Hayashi Y, Skwarczynski M, Hamada Y, Sasaki M, Kimura T and Kiso Y: O-N intramolecular acyl migration reaction in the development of prodrugs and the synthesis of difficult sequence-containing bioactive peptides. Biopolymers 2004, 76:344-56. I Article I PubMed

23. Sohma Y, Sasaki M, Hayashi Y, Kimura T and Kiso Y: Novel and efficient synthesis of difficult sequence-containing peptides through $\mathrm{O}-\mathrm{N}$ intramolecular acyl migration reaction of O-acyl isopeptides. Chem Commun (Camb) 2004, 124-5. I Article I PubMed

24. Hussein WM, Liu TY, Toth I and Skwarczynski M: Microwave-assisted synthesis of difficult sequence-containing peptides using the isopeptide method. Org Biomol Chem 2013, 11:2370-6. | Article I PubMed

25. Yoshiya T, Taniguchi A, Sohma Y, Fukao F, Nakamura S, Abe N, Ito N, Skwarczynski M, Kimura T, Hayashi $Y$ and Kiso Y: "O-acyl isopeptide method" for peptide synthesis: synthesis of forty kinds of "O-acyl isodipeptide unit" Boc-Ser/Thr(Fmoc-Xaa)-OH. Org Biomol Chem 2007, 5:1720-30. | Article | PubMed

26. Sohma Y, Taniguchi A, Skwarczynski M, Yoshiya T, Fukao F, Kimura T, Hayashi $Y$ and Kiso Y: 'O-Acyl isopeptide method' for the efficient synthesis of difficult sequence-containing peptides: use of 'O-acyl isodipeptide unit'. Tetrahedron Lett 2006, 47:3013-3017. | $\underline{\text { Article }}$

27. Skwarczynski M, Fuaad A. A. H. A, Rustanti L, Ziora Z. M, Aqil M, Batzloff M. R, Good M. F and Toth I: Group A streptococcal vaccine candidates based on the conserved conformational epitope from M protein. Drug Delivery Lett 2011, 1:2-8. | Article

28. Skwarczynski M, Parhiz B. H, Soltani F, Srinivasan S, Kamaruzaman K. A. Lin I.-C and Toth I: Lipid Peptide Core Nanoparticles as Multivalent Vaccine Candidates against Streptococcus pyogenes. Aust. J. Chem 2012, 65:35-39. | Article

29. Peek $L$, Middaugh CR and Berkland C: Nanotechnology in vaccine delivery. Adv Drug Deliv Rev 2008, 60:915-28. | Article | PubMed

30. Xiang SD, Scholzen A, Minigo G, David C, Apostolopoulos V, Mottram PL and Plebanski $\mathrm{M}$ : Pathogen recognition and development of particulate vaccines: does size matter? Methods 2006, 40:1-9. | Article | PubMed

31. Zhong W, Skwarczynski M and Toth, I: Lipid Core Peptide System for Gene, Drug, and Vaccine Delivery. Aust. J. Chem 2009, 62:956-967. | Article

32. Zaman M, Abdel-Aal AB, Fujita Y, Ziora ZM, Batzloff MR, Good MF and Toth I: Structure-activity relationship for the development of a self- adjuvanting mucosally active lipopeptide vaccine against Streptococcus pyogenes. J Med Chem 2012, 55:8515-23. | Article | PubMed

33. Skwarczynski M, Kamaruzaman KA, Srinivasan S, Zaman M, Lin IC, Batzloff MR, Good MF and Toth I: M-protein-derived conformational peptide epitope vaccine candidate against Group A Streptococcus. Curr Drug Deliv 2013, 10:39-45. | Article | PubMed

34. Brandt ER, Sriprakash KS, Hobb RI, Hayman WA, Zeng W, Batzloff MR, Jackson DC and Good MF: New multi-determinant strategy for a group A streptococcal vaccine designed for the Australian Aboriginal population. Nat Med 2000, 6:455-9. | Article | PubMed

35. Zhong W, Skwarczynski M, Simerska P, Good M. F and Toth, I: Development of highly pure alpha-helical lipoglycopeptides as selfadjuvanting vaccines. Tetrahedron 2009, 65:3459-3464. | Article

36. Zhong W, Skwarczynski M, Fujita Y, Simerska P, Good, M. F and Toth I: Design and Synthesis of Lipopeptide-Carbohydrate Assembled Multivalent Vaccine Candidates Using Native Chemical Ligation. Aust. J. Chem 2009, 62:993-999. I Article

37. Hayashi Y, Skwarczynski M, Hamada Y, Sohma Y, Kimura T and Kiso Y: A novel approach of water-soluble paclitaxel prodrug with no auxiliary and no byproduct: design and synthesis of isotaxel. J Med Chem 2003, 46:3782-4. | Article | PubMed

38. Abdel-Aal AB, Zaman M, Fujita Y, Batzloff MR, Good MF and Toth I: Design of three-component vaccines against group $A$ streptococcal infections: importance of spatial arrangement of vaccine components. $J$ Med Chem 2010, 53:8041-6. | Article | PubMed

39. Smith A: Fibril formation by short synthetic peptides. Subcell Biochem 2012, 65:29-51. | Article | PubMed

40. Sohma Y, Hirayama Y, Taniguchi A, Mukai H and Kiso Y: 'Click peptide' using production of monomer Abeta from the O-acyl isopeptide: application to assay system of aggregation inhibitors and cellular cytotoxicity. Bioorg Med Chem 2011, 19:1729-33. | Article | PubMed

\section{Citation:}

Skwarczynski M, Kowapradit J, Ziora ZM and Toth I: pH-triggered peptide self-assembly into fibrils: a potential peptide-based subunit vaccine delivery platform. Bio Chem Comp 2013, 1:2. http://dx.doi.org/10.7243/2052-9341-1-2 